\title{
Cystic Hygroma
}

National Cancer Institute

\section{Source}

National Cancer Institute. Cystic Hygroma. NCI Thesaurus. Code C3724.

A benign lymphatic neoplasm usually arising from the neck and characterized by cystic

dilation of the lymphatic vessels. 